\title{
Abdominal compartment syndrome: the importance of urinary catheter placement in measuring intra- abdominal pressure
}

\author{
Muzzammil Ali
}

New Cross Hospital, Wolverhampton, UK

\section{Correspondence to} Dr Muzzammil Ali, muzzammil.ali@nhs.net

Accepted 24 September 2018

\section{DESCRIPTION}

A 27-year-old man with a background of alcohol excess presented to the surgical assessment unit (SAU) with abdominal pain. On clinical examination, he was tender in his epigastric and left-upper quadrant. The blood results of note were a white cell count of $21 \times 10^{9} / \mathrm{L}, \mathrm{C}$ reactive protein $332 \mathrm{mg} / \mathrm{L}$ and amylase $812 \mathrm{U} / \mathrm{L}$. He deteriorated quite quickly on the SAU with agitation, type 1 respiratory failure and hypotension. He required intubation and ventilation, and to be started on vasopressors. A CT of his abdomen and pelvis showed features in keeping with necrotising pancreatitis with a collection in the lesser sac (figure 1). He was managed conservatively in the intensive care unit with vasopressors, intravenous fluids, nasogastric feeds and antimicrobials.

On day 2, he developed increasing abdominal distension. His intra-abdominal pressure (IAP) was measured via his urinary catheter and was found to be $13 \mathrm{mmHg}$. A diagnosis of intra-abdominal hypertension (IAH) secondary to acute pancreatitis was made. On the advice of the surgical team, this was managed conservatively with regular monitoring of IAP.

On day 3 however, his IAP had gradually increased to $17 \mathrm{mmHg}$ and then later that day to $22 \mathrm{mmHg}$. This coincided with higher peak airway pressures and increasing amounts of pressure support to achieve appropriate ventilation (synchronized intermittent mandatory ventilation)-his pressure support had increased from 10 to 25 . A chest X-ray was unremarkable. Due to this respiratory compromise, a diagnosis of abdominal

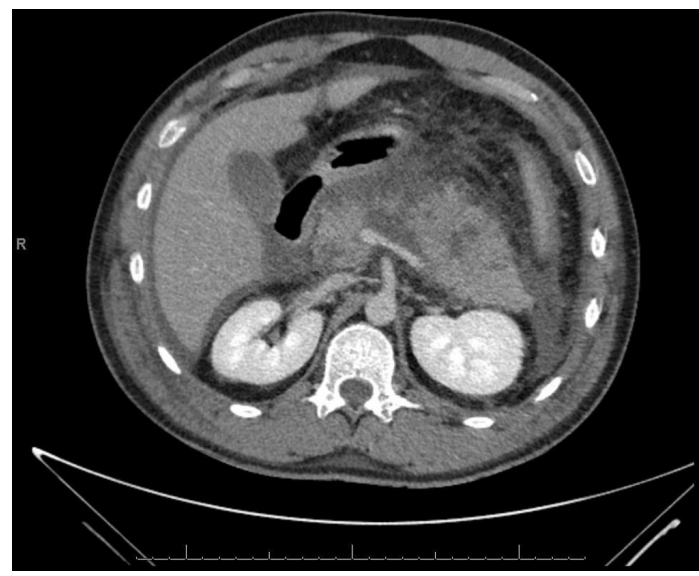

Figure 1 CT scan of abdomen and pelvis showing features of necrotising pancreatitis.

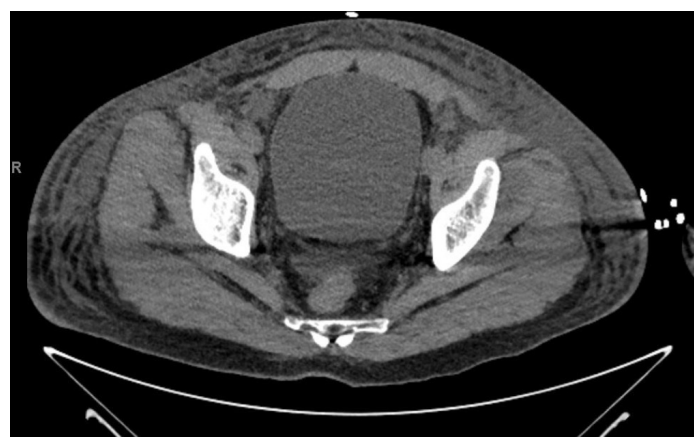

Figure 2 CT scan of abdomen and pelvis showing bladder distention.

compartment syndrome (ACS) was made. His target mean arterial pressure (MAP) was increased with norepinephrine to increase his abdominal perfusion pressure (APP). Subsequent surgical review deemed a continued monitoring strategy as appropriate.

On day 4 however, his IAP continued to climb with little change in his ventilatory requirement. In spite of having an hourly urine output in excess of $100 \mathrm{~mL} /$ hour, his creatinine had gone from $64 \mu \mathrm{mol} / \mathrm{L}$ to $172 \mu \mathrm{mol} / \mathrm{L}$ with a static base excess. Over the next few hours, his IAP had increased from $22 \mathrm{mmHg}$ to $31 \mathrm{mmHg}$ to $41 \mathrm{mmHg}$. On the advice of the surgical team, he had an urgent CT of his abdomen and pelvis. This showed similar features to the previous CT but surprisingly with a grossly distended urinary bladder (figure 2). The urinary catheter balloon was not present in the bladder but was in the penile urethra (figure 3). This was unexpected in the context of large volumes of clear urine without haematuria.

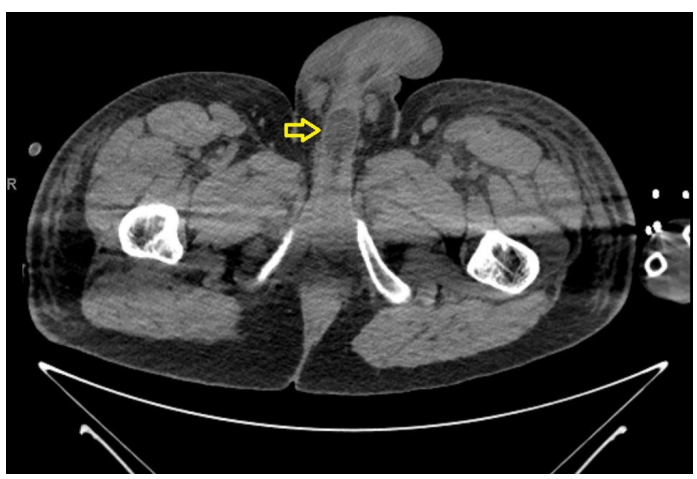

Figure 3 CT scan of abdomen and pelvis showing balloon of catheter in penile urethra (arrow). 
The patient's urinary catheter balloon was deflated, advanced and the balloon reinflated. There was in excess of $1 \mathrm{~L}$ residual

\section{Learning points}

Abdominal compartment syndrome (ACS) is defined as new organ dysfunction in the presence of intra-abdominal hypertension (IAH). It can occur in many conditions including trauma, burns, abdominal sepsis, ascites, postabdominal surgery, intraperitoneal bleeding, ruptured abdominal aortic aneurysm and pancreatitis. Intra-abdominal pressure (IAP) cannot be measured radiologically. The diagnosis of ACS therefore requires indirect IAP measurement via intragastric, intracolonic, intravesical or inferior vena cava catheters. The standard method is intravesical (bladder).

- If an intravesical approach is used to measure IAP, it is important to ensure that the catheter is appropriately sited in the bladder. If it is not, then this can result in a spuriously elevated IAP. Because sedated patients cannot communicate discomfort, a urinary catheter can be displaced even in the presence of high urinary volumes. A bladder scan can help to assess displacement.

- The management of ACS consists of careful observation and supportive care. Because APP=MAP-IAP, patients may benefit by an increased MAP using vasopressors such as norepinephrine to improve perfusion to the abdominal viscera. In some cases, surgical decompression may be required. This occurs after carefully weighing the benefits of decompression with the risks of performing this intervention. volume. A bladder scan confirmed an undistended bladder. The subsequently measured IAP was $22 \mathrm{mmHg}$ as measured on day 3. It was likely that the urinary catheter was displaced into the penile urethra with repeated IAP measurements. This lead to a spuriously elevated IAP, urinary retention and features of postrenal failure.

Over the next 5 days with conservative management, his IAP had gradually reduced and renal function normalised. On day 10, his IAP was measured at $7 \mathrm{~mm} \mathrm{Hg}$. The patient was later successfully extubated and made a full recovery.

$\mathrm{IAH}$ is defined as a sustained intra-abdominal pressure $\geq 12 \mathrm{~mm} \mathrm{Hg} .{ }^{12}$ ACS is defined as a sustained IAP $>20 \mathrm{~mm} \mathrm{Hg}$ that is associated with new organ dysfunction. ${ }^{12}$ In our case, the respiratory compromise that occurred in the context of raised IAH made the diagnosis of ACS possible. Other organ systems that can be affected include cardiac, renal, gastrointestinal, hepatic and central nervous system.

Contributors MA is the sole author

Funding The authors have not declared a specific grant for this research from any funding agency in the public, commercial or not-for-profit sectors.

Competing interests None declared.

Patient consent Obtained.

Provenance and peer review Not commissioned; externally peer reviewed.

\section{REFERENCES}

1 Malbrain ML, Cheatham ML, Kirkpatrick A, et al. Results from the international conference of experts on intra-abdominal hypertension and abdominal compartment syndrome. I. Definitions. Intensive Care Med 2006;32:1722-32.

2 Vidal MG, Ruiz Weisser J, Gonzalez F, et al. Incidence and clinical effects of intraabdominal hypertension in critically ill patients. Crit Care Med 2008;36:1823-31.

Copyright 2018 BMJ Publishing Group. All rights reserved. For permission to reuse any of this content visit http://group.bmj.com/group/rights-licensing/permissions.

BMJ Case Report Fellows may re-use this article for personal use and teaching without any further permission.

Become a Fellow of BMJ Case Reports today and you can:

- Submit as many cases as you like

- Enjoy fast sympathetic peer review and rapid publication of accepted articles

- Access all the published articles

- Re-use any of the published material for personal use and teaching without further permission

For information on Institutional Fellowships contact consortiasales@bmjgroup.com

Visit casereports.bmj.com for more articles like this and to become a Fellow 